Kelaniya Journal of Human Resource Management

Volume 11, Number 01 - January 2016

DOI: http://doi.org/10.4038/kjhrm.v11i1.25

\title{
Factors Affecting Job Satisfaction of Class III Officers of Sri Lanka Administrative Service
}

\author{
S. D. N. S. Jayasena ${ }^{1}$ and S. S. Weligamage ${ }^{2}$

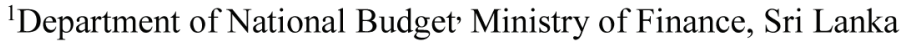 \\ ${ }^{2}$ Department of Finance, Faculty of Commerce and Management Studies, \\ University of Kelaniya, Sri Lanka \\ 1nilukajayasena@gmail.com, ${ }^{2}$ susima@kln.ac.lk
}

\begin{abstract}
The Sri Lanka Administrative Service (SLAS) is the main administrative service of the Sri Lankan Government, with civil servants engaged both in the Central Government as well as in the provincial councils. Purpose of this research was to identify the factors affecting Job Satisfaction of Grade III officers of Sri Lanka Administrative Service (SLAS) and to identify the level of satisfaction. Primary Data were gathered using a structured questionnaire and structured interviews. The data were summarized using descriptive statistics. Through correlation and regression analysis the factors affecting Job Satisfaction of Grade III officers of SLAS were identified. Findings revealed that demographic variables and Pay, Promotion, Supervision, Fringe Benefits and Contingent Rewards are the determinants of Job Satisfaction of the target population. Further it was suggested that increasing the Base Pay, introducing a performance based promotion scheme, fair distribution of training opportunities and granting transport facilities will increase the level of Job Satisfaction.
\end{abstract}

Keywords: Job Satisfaction, Facets of Job Satisfaction, Demographic Variables

\section{Introduction}

The Sri Lanka Administrative Service (SLAS) is the main administrative service of the Sri Lankan Government, with civil servants engaged both in the Central Government as well as in the provincial councils. With a prestigious history of two centuries, the SLAS continues to render its services to our country and its people, following the motto; "Service First!". In 2005 four grades were introduced to Sri Lanka Administrative Service, namely, 
Special Grade, Grade I, Grade II, Grade III. These officers are attached to Provincial Councils, Divisional Administration and Ministries and Departments of the Central government.

SLAS Class III officers serve as Assistant District Secretaries, Assistant Secretaries, Assistant Commissioners, Assistant Directors, Assistant Divisional Secretaries, Assistant Controllers, Assistant Forest Conservator, Assistant Manager, and Secretary to Urban Councils, Assistant Charity commissioner and Assistant Municipal commissioners. Recently, Social media like Facebook had become platforms to express the dissatisfaction of Class III officers of SLAS. Public organisations are established to provide service to the public. Officers are responsible in executing the policies established by the parliament. However Public Sector is always being criticised on the grounds of low performance and high inefficiency. Nevertheless, measures are not being taken to identify the root causes of these symptoms.

Being the Premier Service in the Public Sector SLAS secures a prestigious recognition among the public. When contemplating on SLAS, it is also perceived that the level of job satisfaction has more effect on performance. Matching goals of the officer and organisational goals is of paramount importance. Class III officers represent, 56\% of total SLAS officers. It is evident that the majority of SLAS officers are in Class III. Job Satisfaction of SLAS Class III officers will be one of the key determinants of improvement of performance and quality of service rendered by them. Even though Job Satisfaction has a material impact on job performance and efficiency and effectiveness of the officers no attempt had yet been made to identify the factors affecting Job Satisfaction of SLAS Class III officers. Therefore, identifying the factors affecting Job Satisfaction of Class III officers and giving recommendation to uplift the Job satisfaction has a material impact on the overall service.

\section{Literature Review}

Abraham Maslow's Theory, (Maslow, 1943), concerned the fulfilment of fundamental human needs. Spector (1997) defines job satisfaction as how people feel about their jobs and different aspects of their jobs. Hinai and Bjracharya (2014), had concluded in their research conducted on "A Study 
on the Factors affecting Job Satisfaction of Academic Staff in Higher Education Institution", six factors namely, Remuneration \& development, Management Support, students, collegues, workload and status, affect job satisfaction of academics. Researchers had concluded that job satisfaction strongly correlates with promotion opportunities. (McCausland, W., Pouliakas, K. and Theodossiou, I. 2005.)

According to Locke (1976) job satisfaction is "a pleasurable or positive emotional state resulting from the appraisal of one's job experience" and three dimensions of job satisfactions developed. Clark (1996) had found hours of work has a significant negative effect on overall job satisfaction. He also found that stronger negative effect on satisfaction with pay.

Kaiser (2014), found that specific intrinsic motivators, like work content and customer contact, are utilized to gain job satisfaction rather than extrinsic motivators like payment. The research conducted on "The Determinants of Job Satisfaction in Public Service Organisations" by Muhammad Ashraf et al (2013), had concluded that here is a positive relationship between job satisfaction of the employees in Karachi Water and Sewerage Board and Demographic variables (age, gender, education and job task), work environment variables (task identity, task importance, skill diversity and working condition) and Managerial Control variables (organisation policy, compensation, employee relation and empowerment).

Simin Bemana et al (2013), had revealed that there is a significant negative relationship between job stress and job satisfaction. Further the results had shown that gender difference has no impact on job stress and job satisfaction. Masood et al (2014), had found a significant relationship between working conditions, Job Safety and security, Training and Development and Employee Empowerment on Employee Satisfaction and Job Performance. Though, Pay and promotion has no significant relation with Job Performance. Further they have found that Employee Satisfaction has a significant negative relation with turnover intention.

Jain and Kaur (2014) conducting a research on Impact of work environment on Job Satisfaction had revealed workload, stress, overtime, fatigue, boredom are some factors to increase job dissatisfaction. On the other hand good 
working condition, refreshment \& recreation facility, health \& safety facility, fun at workplace increase the degree of job satisfaction.

When perusing the previous literature it is evident that no research had been so far conducted in identifying factors affecting Job Satisfaction of Class III officers of SLAS in Sri Lanka. . Even though Job Satisfaction is a determinant of performance, limited measures are taken to enhance the Job Satisfaction of employees both in private and public sector in Sri Lanka. Since the Research Culture is not well established as yet in the country attention had not been paid to identifying needs of employees and thereby increase their morale through practical solutions to their needs. Therefore, nine facets of job satisfaction were recognized for this study as pay, promotion, supervision, benefits, contingent rewards, operating procedures, co-workers, nature of the work and communication (Spector 1997 Spector, 1986).

\section{Research Methodology}

\subsection{Population and Sampling Techniques}

The population of this study include Class III officers of SLAS (1266) and 180 officers included in the sample, out of which 128 responded favourably. The response rate of the study was $71 \%$.

\subsection{Conceptual Framework}

The Conceptual Framework is illustrated in figure 1 below. The Independent Variable are Demographic Variables and the Nine Job Facets as mentioned in Spector's (1997) Job Satisfaction Survey. The Dependent Variable is the Job Satisfaction. 


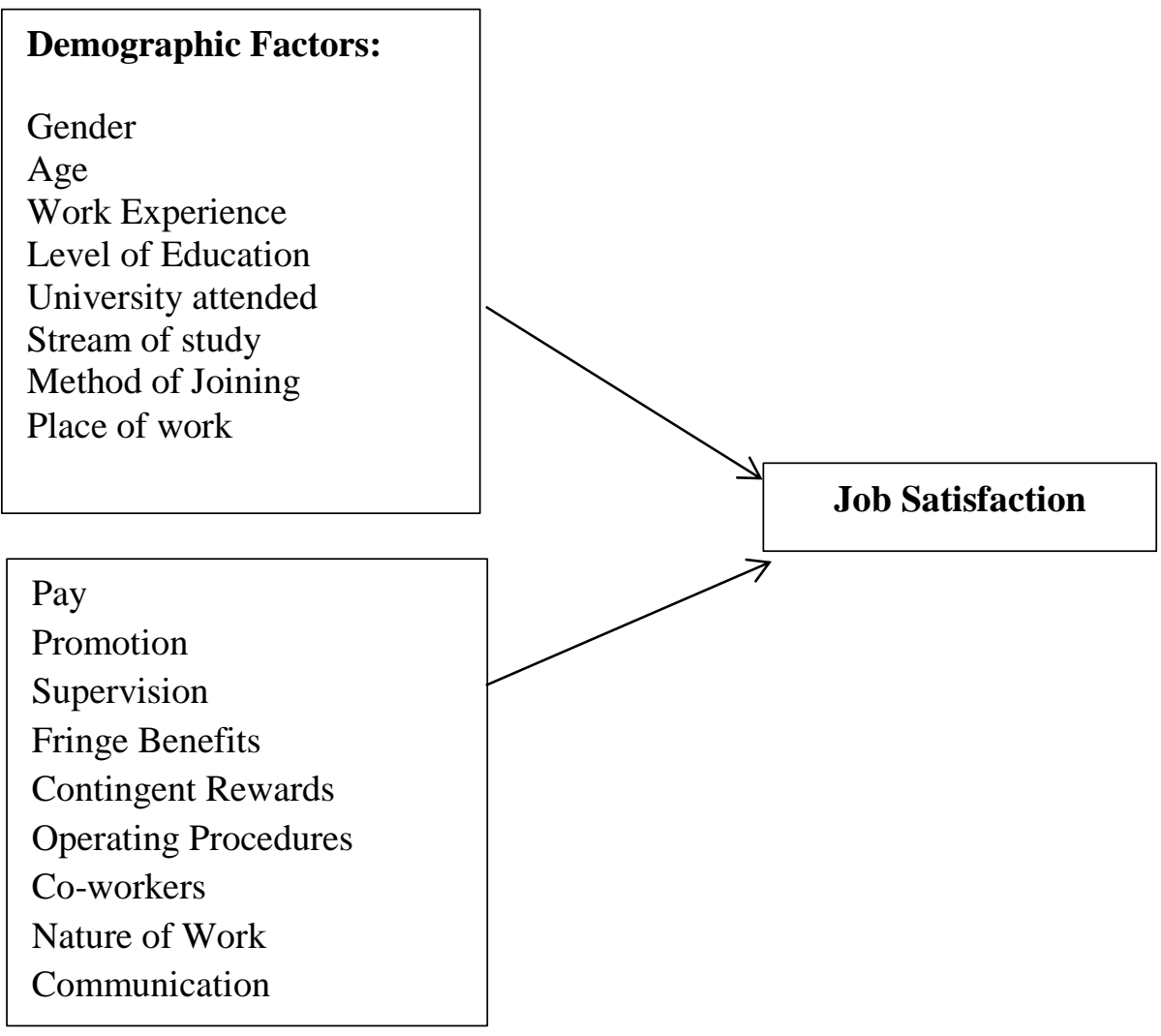

Figure 1: The Conceptual Framework

\subsection{Research Hypotheses}

Based on above conceptual framework following 10 hypotheses were developed.

- There is a positive relationship between Job Satisfaction and Demographic Variables

- There is a strong positive relationship between Pay and Job Satisfaction.

- There is a strong positive relationship between Promotion and Job Satisfaction.

- There is a strong positive relationship between Supervision and Job Satisfaction. 
- There is a strong positive relationship between Fringe Benefits and Job Satisfaction.

- There is a strong positive relationship between Contingent Rewards and Job Satisfaction.

- $\quad$ There is a strong positive relationship between Operating conditions and Job Satisfaction.

- There is a strong positive relationship between Co-workers and Job Satisfaction.

- There is a strong positive relationship between Nature of Work and Job Satisfaction.

- There is a strong positive relationship between Communication and Job Satisfaction.

\subsection{Data Collection}

Primary data were collected using a Questionnaire consisting of two sections. Structured interviews were held with 10 officers. Secondary data was sought from the internet, Journals, previous researches and publications.

The respondents were requested to complete the Job Satisfaction Survey-JSS developed by Paul Spector along with the Demographic information. The Job Satisfaction Survey, JSS is a scale which is used to assess employee attitudes about the job as well as the aspects of the job. JSS is available for researchers free of charge for use for non-commercial purposes (Spector, 1997). It consists of 36 questions coming under nine facets. The nine facets are namely Pay, Promotion, Supervision, Fringe Benefits, Contingent Rewards (performance based rewards), Operating Procedures (required rules and procedures), Co-workers, Nature of Work, and Communication. Each facet is assessed with four items. The total score is computed from all items.

Summated rating scale format is used, with six choices per item ranging from "strongly disagree" to "strongly agree". Items are written in both directions that is they are both positive and negative worded. Negatively worded items must be reversed scored. It is assumed that agreement with positively-worded items and disagreements with negatively-worded items represent satisfaction and vice versa. 
Structured interview was held with 12 Grade III SLAS Officers. Each officer was interviewed for 15-20 minutes. Predefined questions were asked from each interviewee in the same order.

The Profile of the Interviewees was as follows. (Table 1) 6 officers out of the 12 were Male officers 4 officers were interviewed under each category of placement.

Table 1: Profile of the Interviewees

\begin{tabular}{|l|l|l|l|}
\cline { 2 - 4 } \multicolumn{1}{c|}{} & \multicolumn{1}{c|}{$\begin{array}{c}\text { Ministries } \\
\text { Departments }\end{array}$} & District Administration & $\begin{array}{c}\text { Provincial } \\
\text { Councils }\end{array}$ \\
\hline Male & 02 & 02 & 02 \\
\hline Female & 02 & 02 & 02 \\
\hline
\end{tabular}

\subsection{Pilot Survey}

A Pilot Survey was conducted in order to verify the reliability of the Questionnaire. Data was collected from 15 Class III SLAS Officers. The reliability scores were above the standard of 0.792 (Cronbach's Alpha). Through the Pilot Study following alterations were made to the Questionnaire.

I. It was decided to change the order of questions (eg: University attended should be followed by the Stream of the Degree)

II. Instead of asking for the name of the University, it was decided to categorise the University attended under Government /Private.

Job Satisfaction is the Dependent Variable of the Research and the Independent Variables are Pay, Promotion, Supervision, Fringe Benefits, Contingent Rewards, Operating Procedures, Co-workers, Nature of Work, Communication and demographic variables. Correlation Analysis and Regression Analysis were used to identify the relationship between the Dependent Variable and Independent Variables. 


\subsection{Reliability}

Internal Reliability of the Questionnaire was checked using Cronbach's alpha. Cronbach's Alpha for the 17 variables ( 8 demographic variables and 9 facets of Job Satisfaction specified in the JSS) in the research was .709, which is well above the standard value, the Questionnaire is reliable.

Table 2 illustrates the reliability of individual dimensions. Reliabilities of Pay, Promotion, Fringe Benefits, and Contingent Rewards are above the standards value of .7 with a Cronbach's Alpha of 0.928, 0.912, 0.889 and 0.954 respectively. The Cronbach Alpha of Supervision, Operating Conditions, and Co-workers, Nature of work and Communication were below the standard of .7, amounting to $0.586,0.453,0.437,0.594$ and 0.543 respectively.

Table 2: Reliability Statistics of Dimensions of Job Satisfaction

\begin{tabular}{lr}
\hline \multicolumn{1}{c}{ Dimension } & Cronbach's Alpha \\
\hline Pay & 0.928 \\
Promotion & 0.912 \\
Supervision & 0.586 \\
Fringe Benefits & 0.889 \\
Contingent Rewards & 0.954 \\
Operating Conditions & 0.453 \\
Co-workers & 0.437 \\
Nature of work & 0.594 \\
Communication & 0.543 \\
\hline
\end{tabular}

The Overall Reliability Statistics of the 9 dimensions of Job Satisfaction amounted to .727 which is above the standard of .7.

\subsection{Data Analysis}

Pearson's Product Moment Correlation coefficient, Regression analysis were performed in order to identify the factors which have a strong impact on Job Satisfaction or Dissatisfaction of the sample. "SPSS 22" software was used to analyse the data obtained by the questionnaire. 


\section{Results and Discussion}

Questionnaire was distributed to 180 Class III SLAS officers and 128 respondents returned the duly filled questionnaire. The response rate was $71 \%$. The completed questionnaires were coded and entered into SPSS data file for generating results. Out of the 128 respondents, 82 were females representing $64 \%$ of the overall respondents whereas 46 were males amounting to $36 \%$ of the Sample. Job Satisfaction of Males respondents was 112 while the same was only 100 of their Female counterparts (Table 3). The results depict that Female respondents are dissatisfies since the score is 100. However the male respondents' dissatisfaction was lower than that of females.

Table 3: Mean Job Satisfaction Score based on Gender

\begin{tabular}{lcrr}
\hline Gender & Mean & N & Std. Deviation \\
\hline Male & 111.9783 & 46 & 19.40388 \\
Female & 100.0244 & 82 & 13.09413 \\
Total & 104.3203 & 128 & 16.61085 \\
\hline
\end{tabular}

56 respondents possessed experience of 1-3 years amounting to $44 \%$ of the sample. 50 respondents amounting to $39 \%$ had a period of service between $3-$ 5 years. Respondents who had a service period more than in the sample were 22 amounting to $17 \%$ of the sample. Table 4 shows the mean job satisfaction score based on experience in SLAS. It is seen that highest Job Satisfaction of 107.8 is reported for those who have a service period more than 5 years while the second highest Job Satisfaction Score is for the sub group whose period of service ranges from 3-5 years with a score of 107.3 and the respondents with a service period from 1-3 years were the least satisfied with a total score of 100.3. 
Table 4: Mean Job Satisfaction Score based on Experience in SLAS

\begin{tabular}{|l|c|c|c|}
\hline \multicolumn{1}{|c|}{ Experience } & Mean & N & Std. Dev \\
\hline 1 - 3 years & 100.2679 & 56 & 9.69253 \\
\hline 3 - 5 years & 107.3200 & 50 & 20.28314 \\
\hline$>$ 5 years & 107.8182 & 22 & 19.61204 \\
\hline Total & 104.3203 & 128 & 16.61085 \\
\hline
\end{tabular}

Job Satisfaction of the age groups could be depicted by Table 5. Mean Job Satisfaction of the respondents in the age group 22-30 years was the minimum of all the 4 age groups. It was only 103, while the Job Satisfaction of the age groups 30-40 years, 40-50 years and 50-90 year were 103.5, 105.8 and 106.7 respectively. All age groups were dissatisfied since the scores lie within the range of 36 to 108 which denotes dissatisfaction.

Table 5: Mean Job Satisfaction Score; Age

\begin{tabular}{cccc}
\hline Age & Mean & N & Std. Deviation \\
\hline 22 -30 years & 103.0000 & 32 & 14.27382 \\
30-40 years & 103.4889 & 45 & 15.22053 \\
40-50 years & 105.7778 & 45 & 19.71719 \\
50-60 years & 106.6667 & 6 & 15.56492 \\
Total & 104.3203 & 128 & 16.61085 \\
\hline
\end{tabular}

There were 73 Graduates in the sample and it was $57 \%$ of the sample and 33 Masters' Degree holders were $26 \%$ of the sample while $17 \%$ were Postgraduate holders, 22 in number. There were 3 respondents who had passed Advanced Level Examination who constituted 2\% of the Sample. Masters' Degree holders reported the highest level of Job Satisfaction of 116. Average Job Satisfaction of a Graduate respondent was 101, whereas the Job Satisfaction of respondents with Postgraduate qualifications reported Job Satisfaction score of 98 (Table 6). 
Table 6: Mean Job Satisfaction Score based on Level of Education

\begin{tabular}{|l|c|c|c|}
\hline \multicolumn{1}{|c|}{ Education Level } & Mean & N & Std. Deviation \\
\hline Graduate & 100.90 & 73 & 11.926 \\
\hline Postgraduate & 98.23 & 22 & 7.257 \\
\hline Masters' & 115.94 & 33 & 23.433 \\
\hline Total & 104.32 & 128 & 16.611 \\
\hline
\end{tabular}

$35 \%$ of the sample (44) had obtained their basic Degree in Bio Science. There were 32 Management graduates, 27 Arts Graduates, 17 Physical Science Graduates and 8 IT graduates representing $25 \%, 21 \%, 13 \%$ and $6 \%$ of the respondents respectively. Respondents with different educations streams were all dissatisfied since the score lie within the range of score denoting dissatisfaction. Bio Science Graduates were the most satisfied group with a mean of 113 while Physical Science degree holders were ranked $2^{\text {nd }}$ with a mean score of 107. Mean Satisfaction Score of Arts, Management and IT graduates were 99, 97.4 and 97 respectively. (Table 7).

Table 7: Mean Job Satisfaction Score under Stream of the Degree

\begin{tabular}{lccl}
\hline \multicolumn{1}{c}{ Degree } & Mean & N & Std. Deviation \\
\hline Management & 97.4063 & 32 & 8.29636 \\
Physical Science & 107.4118 & 17 & 14.60333 \\
Bio Science & 112.8636 & 44 & 21.51429 \\
Arts & 98.8148 & 27 & 11.50598 \\
IT & 97.0000 & 8 & 0.00000 \\
Total & 104.3203 & 128 & 16.61085 \\
\hline
\end{tabular}

$56 \%$ of the sample was recruited from open Competitive Examination and 44\% had been selected from Limited Examination. There were 72 respondents from the Open Competitive Examination and 56 from Limited Examination. Table 8 below shows the mean Job Satisfaction Scores of respondents categorized under the method of recruitment. The Mean Job 
Satisfaction of both categories was in the Dissatisfaction. However the Mean Score of Job Satisfaction of "Open" recruits were higher than that of "Limited" recruits.

Table 8: Mean Job Satisfaction Score based on method of selection

\begin{tabular}{ccrc}
\hline Method & Mean & N & Std. Deviation \\
\hline Open & 105.6250 & 72 & 16.97590 \\
Limited & 102.6429 & 56 & 16.12500 \\
\hline Total & 104.3203 & 128 & 16.61085 \\
\hline
\end{tabular}

$64 \%$ of the respondents $(\mathrm{n}=82)$ were attached to Ministries and Departments in the Central Government. $21 \%$ of the respondents $(n=27)$ were attached to Provincial Councils.15\% ( $\mathrm{n}=19)$ of the respondents were attached to District Administration. Job satisfaction of the respondents attached to Ministries/Departments and District Administration could be seen as "Dissatisfied". However respondents attached to Provincial Councils were "ambivalent" regarding Job Satisfaction as the mean score falls between 108 and 144. Thus it could be concluded that respondents attached to Provincial Councils reported the highest score of Job Satisfaction (Table 9).

Table 9: Mean Score of Job Satisfaction -Place of work

\begin{tabular}{lrrr}
\hline \multicolumn{1}{c}{ Place } & \multicolumn{1}{c}{ Mean } & N & \multicolumn{1}{c}{$\begin{array}{c}\text { Std. } \\
\text { Deviation }\end{array}$} \\
\hline Ministry/Department & 99.3049 & 82 & 10.27846 \\
District Administration & 105.0000 & 19 & 8.42615 \\
Provincial Council & 119.0741 & 27 & 25.76361 \\
\hline Total & 104.3203 & 128 & 16.61085 \\
\hline
\end{tabular}

Pearson's correlation coefficient related to demographic variable could be tabulated as specified in Table 10. As per the table it is observed that there is a correlation between "Experience" and Job Satisfaction which is significant at 0.05 level. The correlation coefficient is 0.195 . 
Table 10: Pearson's correlation coefficient of Demographic Variables

\begin{tabular}{lcc}
\hline \multicolumn{1}{c}{ Variables } & Job satisfaction & PJS \\
\hline Gender & $-.347^{* *}$ & $-.334^{* *}$ \\
Age & .074 & -.053 \\
Experience & $.195^{*}$ & .172 \\
Education & $.350^{* *}$ & $.302^{* *}$ \\
University & -.114 & -.132 \\
Degree & .048 & .060 \\
Method & -.089 & -.035 \\
Place & $.468^{* *}$ & $.335^{* *}$ \\
\hline
\end{tabular}

*. Correlation is significant at the 0.05 level (2-tailed).

Correlation between Gender, Level of Education and place of work is significant at the 0.01 level. The related correlation coefficients are -0.347 , 0.35 and 0.468 respectively. When perusing table 11 it is evident that there is a strong positive relationship between Pay, Promotion, Fringe Benefits and contingent Rewards. There's a positive yet moderate relationship between supervision and Job Satisfaction. There is a positive weak relationship between Operating Conditions and Co-workers and Job Satisfaction of Class III officers of SLAS. Nature of work and Communication correlated weakly and insignificantly with job satisfaction of the sample.

Table 11: Pearson's Correlation coefficient of facets of Job satisfaction

\begin{tabular}{lc}
\hline & Job Satisfaction \\
\hline Pay & $.950^{* *}$ \\
Promotion & $.896^{* *}$ \\
Supervision & $.596^{* *}$ \\
Fringe Benefits & $.818^{* *}$ \\
Contingent Rewards & $.718^{* *}$ \\
Operating Conditions & $.492^{* *}$ \\
Co-workers & $.381^{* *}$ \\
Nature of Work & -.167 \\
Communication & $-.208^{*}$ \\
\hline **. Correlation is significant at the 0.01 level (2-tailed). \\
*. Correlation is significant at the 0.05 level (2-tailed).
\end{tabular}


Following Table depicts the correlation coefficients of perceived Job Satisfaction of the respondents and the facets of Job Satisfaction. It is evident that there is a strong positive relationship between Job Satisfaction and Pay, Promotion, Supervision, Fringe Benefits and Contingent Rewards while there is a positive yet a weak correlation between Operating Conditions and Coworkers. There's a weak, negative relationship between Nature of Work and Communication and Job Satisfaction.

According to the Regression Analysis it was found that there is a strong relationship between Communication, Supervision, Nature of Work, Coworkers, Fringe Benefits, Operating Conditions, Pay, Contingent Rewards, Promotion and PJS (Table 13).

Table 12: Correlation between Facets of Job Satisfaction and perceived Job Satisfaction

\begin{tabular}{lrr} 
Job Facet & Pearson Correlation & Sig. (1tailed) \\
\hline Pay & 0.696 & 0 \\
Promotion & 0.639 & 0 \\
Supervision & 0.514 & 0 \\
Fringe Benefits & 0.605 & 0 \\
Contingent Rewards & 0.571 & 0 \\
Operating Conditions & 0.334 & 0 \\
Co-workers & 0.188 & 0.017 \\
Nature of Work & -0.201 & 0.011 \\
Communication & -0.161 & 0.035 \\
\hline
\end{tabular}

Table 13: Regression Model Summary

\begin{tabular}{lrrrrr}
\hline Model & $\mathrm{R}$ & $\begin{array}{c}\mathrm{R} \\
\text { Square }\end{array}$ & $\begin{array}{c}\text { Adjusted R } \\
\text { Square }\end{array}$ & $\begin{array}{c}\text { Std. } \\
\text { Error }\end{array}$ & $\begin{array}{c}\text { Durbin- } \\
\text { Watson }\end{array}$ \\
\hline 1 & $.757^{\mathrm{a}}$ & .573 & .541 & .541 & 1.552 \\
\hline a. Predictors: (Constant), Communication, Supervision, Nature of Work, Co- \\
workers, Fringe Benefits, Operating Conditions, Pay, Contingent Rewards, \\
Promotion \\
b. Dependent Variable: Job Satisfaction
\end{tabular}


The following ANOVA Table further justifies the above finding since the level of significance is less than .05 (Table 14).

\section{Table 14: ANOVA}

\begin{tabular}{llccccc}
\hline \multicolumn{1}{c}{ Model } & $\begin{array}{c}\text { Sum of } \\
\text { Squares }\end{array}$ & df & $\begin{array}{c}\text { Mean } \\
\text { Square }\end{array}$ & F & Sig. \\
\hline \multirow{3}{*}{$\begin{array}{l}\text { Regression } \\
1\end{array}$ Residual } & 46.369 & 9 & 5.152 & 17.618 & $.000^{\mathrm{b}}$ \\
& Total & 80.506 & 118 & .292 & & \\
\hline
\end{tabular}

a. Dependent Variable: Job Satisfaction

b. Predictors: (Constant), Communication, Supervision, Nature of Work, Coworkers, Fringe Benefits, Operating Conditions, Pay, Contingent Rewards, Promotion

The following table (Table 15) demonstrates the factors which contribute to the difference of level of PJS of the respondents. It can be concluded that Supervision, Contingent Rewards and operating Conditions can bring about a change in the level of Job satisfaction among the respondents.

Table 15: Regression Coefficients

\begin{tabular}{|c|c|c|c|c|c|}
\hline & \multicolumn{2}{|c|}{$\begin{array}{c}\text { Unstandardized } \\
\text { Coefficients }\end{array}$} & \multirow{2}{*}{$\begin{array}{c}\begin{array}{c}\text { Standardized } \\
\text { Coefficients }\end{array} \\
\text { Beta }\end{array}$} & \multirow{2}{*}{$\mathrm{t}$} & \multirow{2}{*}{ Sig. } \\
\hline & $\mathrm{B}$ & $\begin{array}{c}\text { Std. } \\
\text { Error }\end{array}$ & & & \\
\hline (Constant) & -1.563 & .886 & & -1.764 & .080 \\
\hline Pay & .028 & .048 & .140 & .580 & .563 \\
\hline Promotion & -.030 & .069 & -.149 & -.432 & .667 \\
\hline Supervision & .102 & .034 & .231 & 2.971 & .004 \\
\hline Fringe Benefits & .033 & .036 & .185 & .904 & .368 \\
\hline Contingent Rewards & .073 & .032 & .443 & 2.318 & .022 \\
\hline Operating Conditions & .093 & .049 & .264 & 1.919 & .057 \\
\hline Coworkers & -.002 & .051 & -.004 & -.030 & .976 \\
\hline Nature of Work & -.040 & .036 & -.104 & -1.113 & .268 \\
\hline Communication & .043 & .044 & .127 & .964 & .337 \\
\hline
\end{tabular}

a. Dependent Variable: PJS

Structured interview was held with 12 Grade III SLAS Officers and out of the 06 Male respondents 5 were dissatisfied while the other was neutral. Out 
of the 06 Female respondents 3 were satisfied while the rest were dissatisfied. This was contradictory to the findings of the Questionnaire since it reported a higher level of Job Satisfaction in Male respondents when compared with Female respondents. However it could be concluded that this contradiction may be a result of the limitations of interviews.

Going in line with the findings from the Questionnaire Survey, it was perceived that the respondents in District Administration and Provincial Councils were more satisfied than their counterparts in Ministries and Departments in the Central Government. The reasons for this was due to the higher level of autonomy exercised in routine work and the high level of recognition of the officers in District Administration and Provincial Councils.

Salary, Promotion, Training and Development, Recognition and Fringe benefits were identified as the major factors affecting Job Satisfaction of the respondents. However it was observed that their level of Job Satisfaction varies depend on the Supervisors' conduct. Those who admired their supervisor were more satisfied than those who criticised their supervisors. The respondents were in the view that lack of transport facilities, low basic salary, low fringe benefits, high burden of getting through language proficiency examination within first 5 years of service, unequal distribution of training opportunities (both local and Foreign) among Grade III officers and placing officers from other services in SLAS positions bring about dissatisfaction in their career.

The hypotheses (H1 to H6) tested in this research were accepted and H7 to H10 were rejected. Therefore, the study revealed that the Class III SLAS Officers are "Dissatisfied" in general. It was identified through correlation analysis the factors which have strong positive relationship with Job Satisfaction. They are namely, Pay, Promotion, Supervision, Fringe Benefits and Contingent Rewards. However the Regression analysis revealed the factors which have a significant impact in demarcating the level of Job Satisfaction in different individuals are, Supervision, Co-workers and Contingent Rewards.

\section{Conclusion}

It is observed that this profession becomes less popular among Males mainly due to low levels of Monetary and Non-Monetary Rewards available. Further 
the increasing political influences too had fuelled this dissatisfaction and unattractiveness. It could be concluded that Grade III officers of SLAS are dissatisfied. Both demographic factors and dimensions specified in the JSS, namely, Pay, Promotion, Supervision, Fringe Benefits, Contingent Rewards are the major correlated with Job Satisfaction of Grade III SLAS officers, while the Regression analysis depicts that Supervision, Contingent Rewards and Operating Conditions have a significant impact on the level of Job Satisfaction

Following suggestions could be made to improve the level of satisfaction of Grade III officers of SLAS.

i. Increasing the basic salary is the major suggestion to improve the level of satisfaction. According to the views of the respondents that is well below their peers' Base Pay in the Private Sector. On the other hand, since the loans and Pension are granted based on Basic Salary, the pay hikes should be in the form of increasing the base pay.

ii. Promotions should be granted based on performance which will inspire the employees to work harder. At present it is limited to a mere filling up of a format, which doesn't encourage high performers. Further, it takes 17 long years to be promoted to Grade I, which seems rather disappointing. Therefore bringing down the above mentioned figure to a compromising level is needed.

iii. The prevailing "Agrahara Insurance Policy" is less attractive. Therefore even subject to an increased premium, a comprehensive Health Insurance Scheme should be introduced.

iv. There should be a proper assignment of foreign training and biasness should be eliminated from the selection process. Thereby equal opportunities for foreign training should be made available. The general training programmes should be pooled and be assigned based on predefined criteria.

v. Obtaining a Masters' Degree is compulsory to be promoted to Grade I. however the majority were in the view that it should be altered as a "Master' Degree" from a foreign University", since the foreign exposure is essential for an administrator. 
vi. The officers are permitted to apply for a Housing Loan only after completion of 5 years in the Service. However measures should be launched to arrange Official Quarters for the first 5 years of Service. That could be fulfilled through prioritizing the Grade III officers in assigning official Quarters available, which is seldom done.

vii. Transport facilities are not provided for Grade III officers. Transport allowances are granted to officers who are in Grade I or above. Even though transport facility had been a "Motivation Factor" some decades ago, it has become a "Hygiene Factor". That is, the absence of transport facilities leads to dissatisfaction. Therefore it is necessary to provide transport facilities to Grade III officers as well.

Through this research, it could be emphasized that rather than complaining about the inefficiencies and ineffectiveness of Public Sector, measure should be taken to identify the root causes for those issues and then remedial actions should be taken. It was revealed that "Need Assessments" are not periodically conducted prior to certain recruitments in the Public Sector. Comprehensive Research must be conducted on the effectiveness of certain categories of recruitments.

\section{References}

Ashraf M et al (2013), The Determinants of Job Satisfaction in Public Service Organization, European Scientific Journal, Vol .9 (35) 1857 - 7881

Clark, A.E. (1996). Job satisfaction in Britain. British Journal of Industrial Relations, 34(2), 189-217.

Hinai Z. A and Bajracharya A (2014), $13^{\text {th }}$ International Academic Conference, Antibes, IISES

Jain, R and Kaur, S (2014). Impact of work Environment on Job satisfaction, International Journal of Scientific and Research Publications, 4 (01).

Kaiser, L.C (2014) “Job Satisfaction and Public Service Motivation” IZA Discussion Paper No. 7935

Locke L.A. (1976). The Nature and Causes of Job Satisfaction, Handbook of Industrial and Organizational Psychology, Rand McNally Publication Company, Chicago 
Kelaniya Journal of Human Resource Management

Volume 11, Number 01 - January 2016

Maslow, A. H. (1943), "A theory of human motivation", Psychological Bulletin, Vol. 50, pp. 370-396.

McCausland, W., Pouliakas, K. and Theodossiou, I. (2005)."Some Are Punished and Some Are Rewarded: A Study of the Impact of Performance Pay on Job Satisfaction." International Journal of Manpower. 26: 636 - 59.

Simin Bemana et al (2013), "The Relationship among Job Stress and Job Satisfaction in Municipality Personnel in Iran ", World Applied Sciences Journal Vol. 22 (2): 233-238

Spector, P. E. (1985). Measurement of human service staff satisfaction: Development of the Job Satisfaction Survey. American Journal of Community Psychology, 13, 693-713.

Spector, P. E. (1986). Assessing employee job satisfaction with the job satisfaction survey. Mental Retardation Systems, 3, 5-13.

Spector, P. E. (1997). Job satisfaction: Application, assessment, causes, and consequences. Thousand Oaks, CA: Sage. 